University of Nebraska - Lincoln

DigitalCommons@University of Nebraska - Lincoln

Sociology Department, Faculty Publications

Sociology, Department of

$12-2002$

\title{
Perpetrators of Early Physical and Sexual Abuse Among Homeless and Runaway Adolescents
}

Kimberly A. Tyler

University of Nebraska-Lincoln, kim@ktresearch.net

Ana Mari Cauce

University of Washington

Follow this and additional works at: https://digitalcommons.unl.edu/sociologyfacpub

Part of the Sociology Commons

Tyler, Kimberly A. and Cauce, Ana Mari, "Perpetrators of Early Physical and Sexual Abuse Among Homeless and Runaway Adolescents" (2002). Sociology Department, Faculty Publications. 57. https://digitalcommons.unl.edu/sociologyfacpub/57

This Article is brought to you for free and open access by the Sociology, Department of at DigitalCommons@University of Nebraska - Lincoln. It has been accepted for inclusion in Sociology Department, Faculty Publications by an authorized administrator of DigitalCommons@University of Nebraska - Lincoln. 
Published in Child Abuse \& Neglect 26:12 (December 2002), pp. 1261-1274;

doi 10.1016/S0145-2134(02)00413-1 Copyright (c) 2002 Elsevier Science Ltd.

Used by permission. http://www.sciencedirect.com/science/journal/01452134

The Seattle Homeless Adolescent Research and Education Project (SHARE) is supported by the National Institute on Alcohol Abuse \& Alcoholism, grant number AA10253-05-

Ana Mari Cauce and Les B. Whitbeck, Investigators.

Submitted December 18, 2001; revised June 21, 2002; accepted June 28, 2002;

published online October 2, 2002.

\title{
Perpetrators of early physical and sexual abuse among homeless and runaway adolescents
}

\author{
Kimberly A. Tyler* and Ana Mari Cauce** \\ * Department of Sociology, University of Nebraska-Lincoln, \\ 717 Oldfather Hall, Lincoln, NE 68588-0324, USA \\ (Corresponding author) \\ ** Department of Psychology, University of Washington, Seattle, WA, USA
}

\begin{abstract}
Objective: To examine abuse specific variables among homeless and runaway adolescents and to look at perpetrators of childhood abuse.

Method: A total of 372 homeless and runaway adolescents were interviewed using a systematic sampling strategy in metropolitan Seattle. Young people were interviewed on the streets and in shelters by outreach workers in youth service agencies.

Results: Approximately one-half of these young people reported being physically abused and almost one-third experienced sexual abuse. Females experienced significantly higher rates of sexual abuse compared to males, and sexual minority youth experienced significantly higher rates of physical and sexual abuse compared to heterosexual youth. Average duration of physical and sexual abuse was 5 and 2 years, respectively. Both types of abuse were rated as extremely violent by more than half of those who were abused. The average number of different perpetrators of physical and sexual abuse was four and three, respectively. Biological parents were the majority of perpetrators for physical abuse whereas nonfamily members most often perpetrated sexual abuse. Average age of perpetrators was late 20 s to early 30 s and the majority of perpetrators were male for both types of abuse.

Conclusions: The pattern of exploitation and victimization within the family may have serious and cumulative developmental consequences for these youth as they enter the street environment. Early intervention programs are needed to break the cycle of exploitation and abuse that adolescents experience within the family. Without intervention, many of these youth may be at risk of future exploitation and re-victimization out on the street.
\end{abstract}

Keywords: perpetrators, childhood abuse, homeless adolescents 


\section{Introduction}

Although it has been established that many homeless and runaway adolescents have experienced high rates of abuse (Janus, McCormack, Burgess, \& Hartman, 1987; Silbert \& Pines, 1981; Tyler, Hoyt, \& Whitbeck, 2000; Whitbeck \& Simons, 1990), little is known about specific types of abuse, intensity and duration of abuse, physical injuries and/or outcomes surrounding abuse, and disclosure of abuse. Additionally, little research exists on the young person's relationship to the perpetrator.

\section{Abuse specific variables}

Research on the impact of different abuse specific variables (e.g., frequency, duration, intensity) for children in the general population tends to find that greater severity of abuse, abuse that is violent, and a close relationship to the perpetrator are associated with more negative outcomes ( $c f$. Beitchman, Zucker, Hood, DaCosta, \& Akman, 1991; Morrow \& Sorell, 1989). However, almost nothing is known about the different abuse-specific variables among homeless and runaway adolescents. What little information that does exist finds that a higher proportion of females report having experienced sexual abuse compared to their male counterparts (McCormack, Janus, \& Burgess, 1986; Whitbeck and Whitbeck). Another abuse specific variable, although studied to a lesser extent, especially within the abuse literature is sexual identity. Since gay, lesbian, and bisexual youth are often isolated from friends and family members and some research finds that sexual minority youth experience physical and/or sexual abuse perpetrated by family members and/or peers (Martin \& Hetrick, 1988; Remafedi, 1987), it is important to examine sexual identity as a risk factor.

\section{Relationship to the abuser}

Only a handful of studies on homeless and runaway adolescents examine the relationship to the perpetrator. One study of 223 homeless and runaway youth found that biological mothers were listed by shelter staff as the perpetrators in the majority of maltreatment cases, followed by biological fathers, and stepfathers (Powers, Eckenrode, \& Jaklitsch, 1990). Welsh, Archambault, Janus, and Brown (1995) study of Canadian runaways found that caretakers were the most frequent perpetrators of female sexual abuse $(84 \%)$, whereas "others" (55\%) were listed most often for male sexual abuse (Welsh et al., 1995).

\section{Characteristics of the abuser}

Both lone male and female perpetrators have been found to abuse more boys than girls, and female perpetrators tend to abuse younger children (Rudin, Zalewski, \& BodmerTurner, 1994). However, a small percentage (5\%) of sexual offenses against children and youth are committed by females (see Grayston \& DeLuca, 1999 for a review). In terms of age, female perpetrators tend to be in their 20s and 30s (Grayston \& DeLuca, 1999); the mean age for male perpetrators is 41 years ( $c f$. Craisatti \& McClurg, 1996; Romano \& DeLuca, 1996). 


\section{The current study}

Given that very little research exists on abuse specific variables and perpetrators among homeless and runaway adolescents, the current research moves the child abuse literature forward among this high-risk group in important ways. First, we provide information on the different types of abuse, the duration and intensity of the abuse, and outcomes surrounding the abuse. Second, details are provided on the number of perpetrators, relationship to the perpetrator, and the perpetrator's age. Finally, our sample also includes a large number of gay, lesbian, and bisexual youth, which allows us to examine sexual identity as an abuse specific variable.

Understanding the extent of early maltreatment among homeless and runaway adolescents is important since such abuse may have serious and cumulative developmental consequences that may be exacerbated when these youth engage in high-risk behaviors on the street (e.g., trading sex) as a means of survival. Knowing the extent of the abuse and who the perpetrators are is important for tailoring early intervention programs to break the cycle of abuse that adolescents experience within the family because without it, many young people may be at risk of future exploitation and re-victimization on the street.

\section{Hypotheses}

Based on a sample of 372 homeless and runaway adolescents from Seattle, we sought to examine (a) abuse-specific variables and outcomes of physical abuse and sexual abuse among these adolescents and (b) the perpetrators who victimized these young people. Specifically, we hypothesized that females would experience higher rates of sexual abuse and greater intensity compared to males but that the level of physical abuse would not vary. Second, we expected that sexual minority adolescents would experience higher rates of both sexual and physical abuse. Third, we hypothesized that the majority of perpetrators of physical abuse would be biological parents whereas the majority of perpetrators of sexual abuse would be other family members or nonrelatives. We also expected the majority of perpetrators to be male. Finally, based on the literature's modal profile, male perpetrators were expected to be older on average compared to female perpetrators.

\section{Method}

\section{Procedure}

Data are from the Seattle Homeless Adolescent Research and Education Project (SHARE). It is well established that it is not possible to sample randomly homeless populations (Wright, Allen, \& Devine, 1995) since unbiased enumeration is not realistic. Therefore, young people were interviewed using a systematic sampling strategy that maximized locating homeless and runaway youth in metropolitan Seattle. This strategy employed both street intercepts and locale interviewing. Young people were interviewed over a period of 2 years by outreach workers who were trained youth workers with considerable experience interviewing and interacting with this group of young people. The interviewers were very familiar with local street cultures and were already known and trusted by many of the runaways. 
Interviewers approached all available youth who passed through or were at the locale and appeared to be between the ages of 13 and 21. Street intercepts were made by approaching youth in the areas of the city frequented by homeless and runaway adolescents. In addition to solicitations by the interviewers, youth also were recruited through flyers posted in the local agencies and group informational meetings held at the agencies.

Youth were first administered a brief "eligibility" interview. If deemed to be eligible, the study and procedures were explained and informed consent was obtained from interested youth. Eligible youth were between 13 and 21 years of age, spoke English, did not have a stable residence (i.e., the same place to stay each night), and were not physically in the custody of the state. Youth staying at foster care or temporarily housed were also eligible. If the youth had been on the streets less than 1 week, parental permission was obtained prior to the interview. The questionnaire took approximately 1.5-2 hours to complete and the youth were paid \$25 for the interview. The overall response rate was $95 \%$. This study was approved by the Institutional Review Board at the University of Washington.

\section{Participants}

A total of 372 adolescents were interviewed; $55 \%$ male $(N=203)$ and $45 \%$ female $(N=$ 169). Ages ranged from 13 to 21 with a median of 17 years. A total of 81 adolescents (22\%) identified as gay, lesbian, or bisexual. In terms of race, $48 \%$ were White, $6 \%$ were AfricanAmerican, 5\% were Native American, 3\% were Hispanic, and 2\% were Asian or Pacific Islander. Thirty-six percent of the sample considered themselves biracial or multiracial.

\section{Measures}

Early physical abuse items (see Table 1) were from the Conflict Tactics Scale (Straus \& Gelles, 1990). Early sexual abuse included seven items (see Table 2) that focused on contact and noncontact sexual abuse that the young person may have experienced while living at home (adapted from Whitbeck \& Simons, 1990). The results are based on adolescent self-reports.

Table 1. Type and frequency of early physical abuse and neglect

\begin{tabular}{|c|c|c|c|c|c|}
\hline \multirow{2}{*}{$\begin{array}{l}\text { Before you were on your own (when } \\
\text { you were under } 18 \text { ), how often did } \\
\text { any adult or someone at least } 5 \text { years } \\
\text { older than you ever... }\end{array}$} & \multirow{2}{*}{$\begin{array}{l}\text { Females } \\
N=154 \\
\text { (percent) }\end{array}$} & \multirow{2}{*}{$\begin{array}{l}\text { Males } \\
N=172 \\
\text { (percent) }\end{array}$} & \multirow{2}{*}{$\begin{array}{c}\text { Total } \\
N=326 \\
\text { (percent) }\end{array}$} & \multicolumn{2}{|c|}{$\begin{array}{l}\text { Comparison of } \\
\text { males and females }\end{array}$} \\
\hline & & & & $x^{2}$ & $p$ value \\
\hline Throw something at you in anger & $112(73)$ & $106(62)$ & $218(67)$ & 5.33 & .02 \\
\hline Push, shove, or grab you in anger & $128(83)$ & $138(80)$ & $266(82)$ & 1.07 & .30 \\
\hline Slap you in the face or head & $124(81)$ & $122(71)$ & $246(76)$ & 4.86 & .03 \\
\hline Hit you with some object & $107(70)$ & $124(72)$ & $231(71)$ & .07 & .80 \\
\hline Beat you up (with their fists) & $64(42)$ & $66(38)$ & $130(40)$ & .24 & .62 \\
\hline Threaten you with a gun or knife & $50(32)$ & $47(27)$ & $97(30)$ & .82 & .37 \\
\hline Assault you with a gun or knife & $13(8)$ & $18(11)$ & $31(10)$ & .43 & .51 \\
\hline $\begin{array}{l}\text { Make you go a full day without } \\
\text { food, water, clothing, toilet }\end{array}$ & $32(21)$ & $28(16)$ & $60(18)$ & 1.09 & .30 \\
\hline Abandon you for at least 24 hours & $73(47)$ & $70(41)$ & $143(44)$ & 1.38 & .24 \\
\hline
\end{tabular}


Table 2. Type and frequency of early sexual abuse

\begin{tabular}{|c|c|c|c|c|c|}
\hline \multirow{2}{*}{$\begin{array}{l}\text { Before you were on your own (when } \\
\text { you were under } 18 \text { ), how often did } \\
\text { any adult or someone at least } 5 \text { years } \\
\text { older than you ever... }\end{array}$} & \multirow{2}{*}{$\begin{array}{c}\text { Females } \\
N=144 \\
\text { (percent) }\end{array}$} & \multirow{2}{*}{$\begin{array}{l}\text { Males } \\
N=166 \\
\text { (percent) }\end{array}$} & \multirow{2}{*}{$\begin{array}{c}\text { Total } \\
N=310 \\
\text { (percent) }\end{array}$} & \multicolumn{2}{|c|}{$\begin{array}{l}\text { Comparison of } \\
\text { males and females }\end{array}$} \\
\hline & & & & $x^{2}$ & $p$ value \\
\hline Ask you to do something sexual & $38(26)$ & $30(18)$ & $68(22)$ & 3.07 & .08 \\
\hline Make you watch them do something sexual & $14(10)$ & $15(9)$ & $29(9)$ & .03 & .86 \\
\hline $\begin{array}{l}\text { Make you show your private parts } \\
\text { in person or for a camera }\end{array}$ & $18(13)$ & $14(8)$ & $32(10)$ & 1.43 & .23 \\
\hline Have you touch them sexually & $25(17)$ & $21(13)$ & $46(15)$ & 1.36 & .24 \\
\hline Kiss or touch you sexually & $43(30)$ & $21(13)$ & $64(21)$ & 13.45 & .00 \\
\hline Force you to do something sexual & $42(29)$ & $20(12)$ & $62(20)$ & 13.26 & .00 \\
\hline Put or try to put something into you sexually & y 23 (16) & $13(8)$ & 36 (12) & 5.10 & .02 \\
\hline
\end{tabular}

\section{Results}

The victims

Frequency, intensity, and duration of physical abuse. Almost one-half (47\%) of the sample reported being physically abused as a child. Similar rates were reported among males (44\%) and females $(51 \%)$, and this difference was not statistically significant $\left(\chi^{2}=1.85 ; p=.17\right)$. The majority of adolescents who were physically abused (87\%) said the abuse first started before the age of $12(M=6.21$ years).

In terms of intensity, adolescents were asked, "how violent would you say the worst physical abuse was (i.e., how forceful or violent did it feel to you)?" The response categories ranged from 1, not at all violent to 7, extremely violent. Of those who were physically abused, 67\% indicated that the abuse was extremely violent. A high rate of extremely violent physical abuse was reported among both males (66\%) and females $(68 \%)$. Only $6 \%$ of males and $2 \%$ of females said that the abuse was not at all violent. The intensity of physical abuse did not significantly differ for males and females $(t=$ $-.56 ; p=.58)$.

The duration of physical abuse ranged from under 1 year to 16 years. Twenty-eight percent reported that the physical abuse lasted 2 years or less; $27 \%$ indicated a period of 3-5 years; almost one-third (30\%) said it lasted 6-9 years; and 15\% reported that the duration was 10 years or more. The average duration of physical abuse was 5.4 years (median $=5.0)$. The median was the same for both males and females (median $=5.0$ ).

Disclosure. The majority of physically abused adolescents (88\%) reported telling an adult about the abuse and $82 \%$ told a friend. Of the people to whom they disclosed, $52 \%$ of the adults and $19 \%$ of the friends were not at all or only somewhat understanding and concerned. Similar rates of disclosure and support were reported by both males and females. 
Type of physical abuse. These young people experienced numerous kinds of physical abuse and/or neglect (see Table 1). The majority have had someone throw something at them in anger $(67 \%)$, been pushed or shoved in anger $(82 \%)$, slapped $(76 \%)$, or hit with an object $(71 \%)$. Females were significantly more likely to have been slapped $\left(\chi^{2}=4.86 ; p=.03\right)$ and to have had something thrown at them in anger $\left(\chi^{2}=5.33 ; p=.02\right)$ compared to males. Thirty percent of youth have been threatened with a gun or knife, $10 \%$ assaulted, and $40 \%$ have been beaten up. Neglect measures indicate that $44 \%$ of the sample reported being abandoned for at least 24 hours and 18\% were punished by having to go a full day without food, water, or clothing.

Sexual orientation. In order to test the importance of sexual identity as an abuse specific variable, heterosexual youth were compared to those who self-identified as gay, lesbian, and/or bisexual for the different types of physical abuse. Results indicated that sexual minority youth were significantly more likely to be neglected including being abandoned for at least 24 hours $\left(\chi^{2}=10.28 ; p=.00\right)$ and having to go a full day without food, water, clothing, or a toilet $\left(\chi^{2}=6.13 ; p=.01\right)$. Sexual minority youth were more likely to have experienced higher rates of almost every type of physical abuse including having had something thrown at them in anger $\left(\chi^{2}=7.10 ; p=.01\right)$, pushed, shoved or grabbed in anger $\left(\chi^{2}\right.$ $=5.99 ; p=.01)$, slapped $\left(\chi^{2}=5.29 ; p=.02\right)$, hit with an object $\left(\chi^{2}=5.79 ; p=.02\right)$, beaten up with fists $\left(\chi^{2}=6.51 ; p=.01\right)$, and threatened with a weapon $\left(\chi^{2}=4.47 ; p=.03\right)$.

Outcomes of physical abuse. In many cases, various injuries resulted from the abuse. Of those who were physically abused, $74 \%$ reported bruises or welts; $48 \%$ indicated lacerations; $12 \%$ said they suffered from broken bones; and $15 \%$ had burns as a result of the physical abuse. Twenty-seven percent of those who were physically abused reported needing to see a doctor, and $21 \%$ reported needing hospitalized care for their injuries. Females were significantly more likely than males to have reported bruises or welts $\left(\chi^{2}=\right.$ $11.24 ; p=.00)$ and lacerations or cuts $\left(\chi^{2}=7.07 ; p=.03\right)$ as a result of the abuse.

Frequency, intensity, and duration of sexual abuse. Many young people were also victims of sexual abuse. That is, $29 \%$ indicated that they were sexually abused as a child. Females reported higher rates (44\%) compared to males (18\%) and this difference was statistically significant $\left(\chi^{2}=28.40 ; p=.00\right)$. The majority of those sexually abused $(78 \%)$ said the abuse first started before the age of $12(M=7.11$ years).

In terms of intensity, adolescents were asked, "how violent would you say the worst sexual abuse was (i.e., how forceful or violent did it feel to you)?" The response categories ranged from 1, not at all violent to 7 , extremely violent. Of those who were sexually abused, more than one-half (52\%) reported that the abuse felt extremely violent. Similar rates of extremely violent sexual abuse were reported by both males and females (49 and $54 \%$, respectively).

The duration of sexual abuse ranged from less than 1 year to 12 years. Although the majority of young people sexually abused reported that the duration was less than 2 years (71\%), 19\% indicated that the abuse lasted 3-5 years, and 10\% said the abuse lasted 6 or more years. The average duration of sexual abuse was 2 years (median $=1.0$ ). A similar mean was found for males and females. 
Disclosure. The majority reported telling an adult about the abuse (92\%), and $78 \%$ of young people confided in a friend. Of the people to whom they disclosed, $21 \%$ of both adults and friends were not at all understanding, supportive, or concerned about the abuse. Similar rates of disclosure and level of support from adults and friends were reported by both males and females.

Type of sexual abuse. Many adolescents reported experiencing numerous types of sexual abuse (see Table 2). Overall, many have been asked to do something sexual (22\%), been forced to do something sexual (20\%), or have been kissed or touched sexually $(21 \%)$ on at least one occasion. Females were significantly more likely to have been kissed or touched sexually $\left(\chi^{2}=13.45 ; p=.00\right)$; forced to do something sexual $\left(\chi^{2}=13.26 ; p=.00\right)$; and to have had someone put or try to put something into them sexually $\left(\chi^{2}=5.10 ; p=.02\right)$ compared to males.

Sexual orientation. In order to test the importance of sexual identity as an abuse specific variable, the different types of sexual abuse were compared for the sexual minority group and the heterosexual group. Results indicated that gay, lesbian, and bisexual youth were significantly more likely to have been asked to do something sexual $\left(\chi^{2}=7.02 ; p=.01\right)$, made to watch someone else do something sexual $\left(\chi^{2}=6.08 ; p=.01\right)$, forced to show their private parts $\left(\chi^{2}=5.88 ; p=.02\right)$, forced to touch someone sexually $\left(\chi^{2}=4.53 ; p=.03\right)$, to have been kissed or touched sexually $\left(\chi^{2}=5.50 ; p=.02\right)$, and more likely to have had someone put or try to put something into them sexually $\left(\chi^{2}=6.43 ; p=.01\right)$ compared to heterosexual young people.

Outcomes of sexual abuse. Sexually abused adolescents also suffered numerous negative side effects as a result of the abuse including having difficulty walking or sitting (17\%); having a pain or itch in their private parts $(13 \%)$; venereal disease $(5 \%)$; and bruising or bleeding (13\%). Moreover, $16 \%$ of those sexually abused reported needing to go to a doctor, and $12 \%$ reported a need for hospitalized care as a result of the sexual abuse. Females were significantly more likely than males to have reported having to see a doctor $\left(\chi^{2}=\right.$ $8.01 ; p=.02)$ and needing to go to the hospital $\left(\chi^{2}=7.95 ; p=.02\right)$ as a result of the abuse.

\section{The perpetrators}

We looked at the person who first physically and sexually abused these young people, along with this person's gender and age. We also examined the number of different perpetrators who had abused these young people prior to their leaving home. (Information on the perpetrators refers to physical abuse and sexual abuse in general rather than to a specific type of abuse such as those reported in Table 1 and Table 2.)

Number of perpetrators of physical abuse. Many young people who were physically abused reported more than three perpetrators. That is, $12 \%$ of youth reported four different perpetrators, $8 \%$ indicated five different people, and 15\% of those physically abused reported that six or more different people have done this to them. The average number of people who had physically abused these adolescents was 4.4 (median $=3.0)$. There was no significant difference in the number of perpetrators for males and females. 
Table 3. Perpetrators who first physically abused homeless adolescents (by perpetrator gender)

\begin{tabular}{|c|c|c|c|c|c|c|}
\hline \multicolumn{3}{|c|}{ Perpetrator and gender Females $(N=123)$} & \multicolumn{2}{|c|}{ Males $(N=134)$} & \multicolumn{2}{|c|}{ Total $(N=257)$} \\
\hline & Number & Percent (\%) & Number & Percent $(\%)$ & Number & Percent $(\%)$ \\
\hline \multicolumn{7}{|c|}{ Biological parent } \\
\hline Male & 41 & 33 & 52 & 39 & 93 & 36 \\
\hline Female & 44 & 36 & 40 & 30 & 84 & 33 \\
\hline Total & 85 & 69 & 92 & 69 & 177 & 69 \\
\hline \multicolumn{7}{|l|}{ Step-parent } \\
\hline Male & 11 & 9 & 12 & 9 & 23 & 9 \\
\hline Female & 0 & - & 1 & 1 & 1 & .4 \\
\hline Total & 11 & 9 & 13 & 10 & 24 & 9 \\
\hline \multicolumn{7}{|c|}{ Relative/older sibling } \\
\hline Male & 3 & 2 & 8 & 6 & 11 & 4 \\
\hline Female & 7 & 6 & 4 & 3 & 11 & 4 \\
\hline Total & 10 & 8 & 12 & 9 & 22 & 8 \\
\hline \multicolumn{7}{|c|}{ Adoptive/foster parent } \\
\hline Male & 2 & 1 & 4 & 3 & 6 & 2 \\
\hline Female & 1 & 1 & 4 & 3 & 5 & 2 \\
\hline Total & 3 & 2 & 8 & 6 & 11 & 4 \\
\hline \multicolumn{7}{|c|}{ Stranger/acquaintance* } \\
\hline Male & 12 & 10 & 8 & 6 & 20 & 8 \\
\hline Female & 2 & 1 & 1 & 1 & 3 & 1 \\
\hline Total & 14 & 11 & 9 & 7 & 23 & 9 \\
\hline
\end{tabular}

Percents have been rounded.

* Stranger/acquaintance refers to nonfamily members.

Perpetrator gender and physical abuse. Characteristics of the person who first physically abused these adolescents are presented by perpetrator gender in Table 3. The majority of perpetrators of physical abuse and neglect were biological parents (69\%). Mothers and fathers were equally likely to physically abuse their children (33 and 36\%, respectively). Adolescent males and females reported similar percentages for biological mothers and fathers. The second most likely perpetrator following the biological parent was a male step-parent (9\%). Again, the reports of victimized males and females were similar. Male strangers/acquaintances were listed with similar frequency (8\%). Other family members, including relatives and older siblings were also listed (8\%), with the perpetrators being evenly split between males (4\%) and females (4\%). Overall, the majority of these adolescents $(90 \%)$ listed a family member as the first person who physically abused them.

Perpetrator age and physical abuse. The average age of the perpetrator who first physically abused these youth was 30.8 years (median $=30.0$ ). The median age for male perpetrators was 30 and for female perpetrators it was 28 years of age. This difference was not statistically significant. The majority of biological parents who physically abused their children 
were between the ages of 26 and $35(N=72)$. The majority of strangers/acquaintances were between 19 and 25 years of age $(N=7)$, whereas the majority of step/adoptive/foster parents fell into the 26-35-year-old category $(N=16)$.

Number of perpetrators of sexual abuse. The majority of youth (57\%) listed one perpetrator of sexual abuse. However, $28 \%$ indicated two or three people, and $15 \%$ reported four or more different perpetrators that have sexually abused them. The average number of different sexual perpetrators was 3.1 (median $=1.0$ ) and there was no significant difference in number of perpetrators for males and females.

Perpetrator gender and sexual abuse. The person who first sexually abused these adolescents is presented by perpetrator gender in Table 4. Step/adoptive/foster parents were the least likely to be perpetrators of sexual abuse (7\%) followed by biological parents (10\%) according to adolescent reports. Within these two groups, adult males were the sole perpetrators against adolescent females (6 and 10\%, respectively) whereas for male adolescents, female perpetrators were also listed ( 3 and $6 \%$, respectively).

Other family members who sexually abused these youth included relatives and older siblings (25\%) with the majority of these perpetrators being male $(22 \%)$. The largest category of perpetrators of sexual abuse were stranger/acquaintances (58\%) with the majority of these being male (47\%). Adolescent males reported being sexually abused by a nonfamily member more often than adolescent females (63\% vs. 55\%, respectively). However,

Table 4. Perpetrators who first sexually abused homeless adolescents (by perpetrator gender)

\begin{tabular}{|c|c|c|c|c|c|c|}
\hline \multirow[t]{2}{*}{ Perpetrator and gender } & \multicolumn{2}{|c|}{ Females $(N=51)$} & \multicolumn{2}{|c|}{ Males $(N=32)$} & \multicolumn{2}{|c|}{ Total $(N=83)$} \\
\hline & Number & Percent $(\%)$ & Number & Percent $(\%)$ & Number & Percent $(\%)$ \\
\hline \multicolumn{7}{|l|}{ Biological parent } \\
\hline Male & 5 & 10 & 1 & 3 & 6 & 7 \\
\hline Female & 0 & - & 2 & 6 & 2 & 3 \\
\hline Total & 5 & 10 & 3 & 9 & 8 & 10 \\
\hline \multicolumn{7}{|c|}{ Step/adoptive/foster parent } \\
\hline Male & 3 & 6 & 2 & 6 & 5 & 6 \\
\hline Female & 0 & - & 1 & 3 & 1 & 1 \\
\hline Total & 3 & 6 & 3 & 9 & 6 & 7 \\
\hline \multicolumn{7}{|l|}{ Relative/older siblings } \\
\hline Male & 13 & 25 & 5 & 16 & 18 & 22 \\
\hline Female & 2 & 4 & 1 & 3 & 3 & 3 \\
\hline Total & 15 & 29 & 6 & 19 & 21 & 25 \\
\hline \multicolumn{7}{|l|}{ Stranger/acquaintance* } \\
\hline Male & 28 & 55 & 11 & 34 & 39 & 47 \\
\hline Female & 0 & - & 9 & 28 & 9 & 11 \\
\hline Total & 28 & 55 & 20 & 63 & 48 & 58 \\
\hline
\end{tabular}

Percents have been rounded.

* Stranger/acquaintance refers to nonfamily members. 
young women reported that all of the nonfamily members who sexually abused them were male whereas among young men, $34 \%$ of the perpetrators were male and $28 \%$ were female.

Perpetrator age and sexual abuse. Overall, the average age of perpetrators who first sexually abused these young people was 26.2 years (median $=22.5$ ). Male perpetrators were significantly older than females (28 years vs. 19 years, respectively). Due to the small numbers in each cell, these data should be interpreted with caution. The majority of relatives and/ or older siblings $(N=10)$ who sexually abused these young people were less than 19 years of age. Few ages were given for biological parents and caretakers.

Summary. Overall, $82 \%$ of sexual perpetrators were male; the corresponding rate for physical perpetrators was $59 \%$. Broken down by adolescent sex, girls reported that $96 \%$ of all sexual perpetrators were male; among boys, the rate was 59\%. For physical abuse, the percentage of male perpetrators dropped to $56 \%$ for females and increased slightly to $63 \%$ for males.

\section{Discussion}

Consistent with previous findings, homeless and runaway adolescents experience high rates of sexual and physical abuse prior to leaving home (Janus et al., 1987; Molnar, Shade, Kral, Booth, \& Watters, 1998; Silbert; Tyler and Whitbeck). The sexual abuse rate of $29 \%$ found in the current study ( $44 \%$ for females) is somewhat lower than the findings of Janus et al. (1987) and Silbert and Pines (1981) who found rates in excess of 50\%. Rates of physical abuse in a study of homeless and runaway adolescents in the Midwest (Whitbeck \& Hoyt, 1999) were similar to those reported in the current study. Most studies based on self-reports of homeless and runaway adolescents find high rates of physical and sexual abuse and the current study is no exception.

Several important findings from the current study add to the literature on child abuse and homeless adolescents. First, we found that the majority of adolescents rated the abuse as extremely violent, lasting for at least 1 year. Second, young people whom self-identified as gay, lesbian, or bisexual experienced high rates of physical and sexual abuse. Third, the characteristics of the victimizers revealed that over one-third (35\%) of those abused reported four or more different perpetrators and $41 \%$ of sexually abused males said that the perpetrator was female. Finally, young people who were abused reported a lack of support and concern from adults.

Gay, lesbian, and bisexual youth experienced significantly higher rates of almost every type of both physical and sexual abuse compared to their heterosexual counterparts indicating the importance of sexual identity as an abuse specific variable. It is possible that the young persons' sexual orientation leads to conflict and strain with their caretakers and this makes it difficult for them to live at home ( $c f$. Martin \& Hetrick, 1988; Remafedi, 1987). Once their sexuality has been revealed, they are at risk of abuse and in some cases, may be forced to leave home (Savin-Williams, 1994).

Not only did many young people experience numerous forms of physical abuse, but $35 \%$ were abused by four or more different perpetrators. One possible explanation is that many homeless and runaway adolescents experience numerous life transitions such as 
changes in family structure (e.g., divorce, separation, remarriage, boy/girlfriend coming and going) (Hagan \& McCarthy, 1997; Whitbeck \& Hoyt, 1999). Having different adults move in and out of the household increases the pool of potential perpetrators that may physically abuse these youth. Another possible explanation may be due to the fact that many homeless and runaway adolescents grow up in troubled families where parents abuse alcohol and drugs and report mental health problems (cf. Stiffman, 1989; Whitbeck \& Hoyt, 1999), which are associated with rejecting behavior and less effective parenting (cf. Whitbeck \& Hoyt, 1999). Adolescents from troubled homes are likely to have siblings who have experienced similar exposure and may display similar types of abusive behavior, therefore, increasing the potential pool of perpetrators.

Regarding sexual abuse, $57 \%$ of young people listed one perpetrator, and the majority of the abuse was committed by a nonfamily member $(58 \%)$ rather than a biological parent. It is possible that unlike physical abuse, which may take place in the open with other family members witnessing the act and seen as a legitimate form of discipline by some families, sexual abuse is more likely to be hidden. For that reason, it is likely that fewer individuals will perpetrate such an act due to the lack of "opportunity." Even though parents are most likely to have "opportunity" because of living in the same household compared to nonfamily members, sexual taboos discourage this. Therefore, one might expect perpetrators of sexual abuse to be outside family members or nonbiological parents.

Even though the majority of sexual perpetrators were men, $41 \%$ of sexually abused males reported a female perpetrator; a percentage much higher than that found in the general population (Grayston \& DeLuca, 1999). One possibility is that these female perpetrators may have had opportunity. That is, $28 \%$ of female perpetrators who sexually abused males in the current study were nonfamily members (e.g., babysitters, neighbors, older friends). Therefore, based on her relationship with the family (e.g., babysitter) the female perpetrator may have had more opportunity compared to others. This explanation is also plausible given the young average age of the female perpetrators in the current study (i.e., 19 years of age).

Although most adolescents reported telling an adult about the abuse, over $75 \%$ of these adults were not concerned or supportive about their situation. It is possible that the adult did not believe them or perhaps did not think the act was serious enough to warrant a report. Additionally, if a child has been sexually abused by his/her mother's boyfriend (i.e., nonfamily member) this may not be something that the mother wants to acknowledge. Given that the majority had no one to turn to, it is not surprising that numerous runaways report leaving home due to abuse. In fact, in the current study, $49 \%$ of adolescents reported running away for the first time due to violence at home, physical abuse, and/or sexual abuse. However, it should be noted that not every child or adolescent who is abused would run away from home and not all runaways have been abused.

Results of the present study are limited by respondents' self-reports. However, participants were informed that their responses would be confidential, and the interviewers were very familiar with local street cultures and were already known and trusted by many of the runaways. For these reasons, it is less likely that the respondents would be motivated to bias their responses. Moreover, comparisons done on runaway adolescents and their parents reveal that these young people do not appear to be over-reporting abuse within the home (Whitbeck, Hoyt, \& Ackley, 1997). Another limitation is the retrospective 
nature of many of the measures, which may have resulted in some over- or under-reporting. For example, some of the perpetrator's ages that were given led us to believe that some adolescents did not know the exact age; therefore, gave a rounded number. Additionally, we caution that even though we report on physical and sexual abuse, not all of the abuse was perpetrated by a caretaker. In some cases the perpetrators were older siblings, neighbors, or acquaintances. Also, the data did not allow us to determine who the perpetrator was for each specific type of abuse but only for sexual abuse and physical abuse in general. Finally, the reports of perpetrators refer to the person who first abused the adolescent. Even though this person may have been a nonfamily member, it is possible that caretakers or other family members subsequently sexually abused the adolescents.

Despite these limitations, this study also has numerous strengths including a large sample of homeless and runaway youth from both shelters and the streets; a large subsample of gay, lesbian, and bisexual youth, which allowed for comparisons; a focus on all three types of maltreatment as well as various forms; identifying sexual identity as an abuse-specific variable; and more detailed information on perpetrators (including females), than that previously found in the literature on homeless adolescents.

\section{Implications}

At the policy level, these results have practical implications for service providers. Foremost is the fact that many of these young people have experienced physical abuse and/ or sexual abuse at home perpetrated by a biological parent, step/adoptive parent, sibling, or relative. Policies that require runaways to return home may only put these youth at further risk of re-victimization by such family members. Additionally, because many of these young people have been physically and emotionally hurt and have trouble trusting adults, sending them back home may only increase the risk of these youth running again. Also, given the young people's level of mistrust with adults, service providers need to recognize that this mistrust may be adaptive given the young people's experiences. The pattern of exploitation and victimization within the family is likely to have serious and cumulative developmental consequences for these youth as they enter the street environment. Early intervention programs are needed to break the cycle of exploitation and abuse that adolescents experience within the family and may again experience on the street. From a prevention perspective, given the level of abuse in some of their backgrounds, once abuse has taken place in the family, it is important to see that the whole family receives intervention and not just the abused and the abuser. Without intervention, some of these youth are at risk of future exploitation and re-victimization on the street.

\section{References}

Beitchman et al., 1991. - J. H. Beitchman, K. J. Zucker, J. E. Hood, G. A. DaCosta, and D. Akman, A review of the short-term effects of child sexual abuse. Child Abuse E Neglect 15 (1991), pp. 537-556.

Craisatti \& McClurg, 1996. - J. Craisatti and G. McClurg, The challenge project: Perpetrators of child sexual abuse in South East London. Child Abuse \& Neglect 20 (1996), pp. 1067-1077.

Grayston \& DeLuca, 1999. - A. D. Grayston and R. V. DeLuca, Female perpetrators of child sexual abuse: A review of the clinical and empirical literature. Aggression and Violent Behavior 4 (1999), pp. 93-106. 
Hagan \& McCarthy, 1997. - J. Hagan and B. McCarthy. Mean streets: Youth crime and homelessness. New York: Cambridge University Press, 1997.

Janus et al., 1987. - M. Janus, A. McCormack, A. W. Burgess, and C. Hartman. Adolescent runaways: Causes and consequences. Lexington, MA: Lexington Books, 1987.

Martin \& Hetrick, 1988. - A. D. Martin and E. S. Hetrick, The stigmatization of the gay and lesbian adolescent. Journal of Homosexuality 15 (1988), pp. 163-183.

McCormack et al., 1986. - A. McCormack, M. Janus, and A. W. Burgess, Runaway youths and sexual victimization: Gender differences in an adolescent runaway population. Child Abuse $\mathcal{E} \mathrm{Ne}-$ glect 10 (1986), pp. 387-395.

Molnar et al., 1998. - B. E. Molnar, S. B. Shade, A. H. Kral, R. E. Booth, and J. K. Watters, Suicidal behavior and sexual/physical abuse among street youth. Child Abuse E Neglect 22 (1998), pp. 213-222.

Morrow \& Sorell, 1989. - K. B. Morrow and G. T. Sorell, Factors affecting self-esteem, depression, and negative behaviors in sexually abused female adolescents. Journal of Marriage and the Family 51 (1989), pp. 677-686.

Powers et al., 1990. - J. L. Powers, J. Eckenrode, and B. Jaklitsch, Maltreatment among runaway and homeless youth. Child Abuse \& Neglect 14 (1990), pp. 87-98.

Remafedi, 1987. - G. Remafedi, Adolescent homosexuality: Psychosocial and medical implications. Pediatrics 79 (1987), pp. 331-337.

Romano \& DeLuca, 1996. - E. Romano and R. V. DeLuca, Characteristics of perpetrators with histories of sexual abuse. International Journal of Offender Therapy and Comparative Criminology 40 (1996), pp. 147-156.

Rudin et al., 1994. - M. M. Rudin, C. Zalewski, and J. Bodmer-Turner, Characteristics of child sexual abuse victims according to perpetrator gender. Child Abuse $\mathcal{E}$ Neglect 19 (1994), pp. 963-973.

Savin-Williams, 1994. - R. C. Savin-Williams, Verbal and physical abuse as stressors in the lives of lesbian, gay male, and bisexual youths: Associations with school problems, running away, substance abuse, prostitution, and suicide. Journal of Consulting and Clinical Psychology 62 (1994), pp. 261-269.

Silbert \& Pines, 1981. - M. H. Silbert and A. M. Pines, Sexual child abuse as an antecedent to prostitution. Child Abuse \& Neglect 5 (1981), pp. 407-411.

Stiffman, 1989. A. R. Stiffman, Physical and sexual abuse in runaway youth. Child Abuse $\mathcal{E}$ Neglect 13 (1989), pp. 417-426.

Straus \& Gelles, 1990. - M. A. Straus and R. J. Gelles. Physical violence in American families: Risk factors and adaptations to violence in 8145 families. New Brunswick, NJ: Transaction Publishers, 1990.

Tyler et al., 2000. - K. A. Tyler, D. R. Hoyt, and L. B. Whitbeck, The effects of early sexual abuse on later sexual victimization among female homeless and runaway youth. Journal of Interpersonal Violence 15 (2000), pp. 235-250.

Welsh et al., 1995. - L. A. Welsh, F. X. Archambault, M. D. Janus, and S. W. Brown. Running for their lives: Physical and sexual abuse of runaway adolescents. New York, NY: Garland Publishing, 1995.

Whitbeck \& Hoyt, 1999. - L. B. Whitbeck and D. R. Hoyt. Nowhere to grow: Homeless and runaway adolescents and their families. New York, NY: Aldine de Gruyter, 1999.

Whitbeck et al., 1997. - L. B. Whitbeck, D. R. Hoyt, and K. A. Ackley, Families of homeless and runaway adolescents: A comparison of parent/caretaker and adolescent perspectives on parenting, family violence, and adolescent conduct. Child Abuse \& Neglect 21 (1997), pp. 517-528.

Whitbeck \& Simons, 1990. - L. B. Whitbeck and R. L. Simons, Life on the streets: The victimization of runaway and homeless adolescents. Youth \& Society 22 (1990), pp. 108-125.

Wright et al., 1995. - J. D. Wright, T. Allen, and J. A. Devine, Tracking nontraditional populations in longitudinal studies. Evaluation and Program Planning 18 (1995), pp. 267-277. 


\section{Résumé}

Objectifs: Examiner les variables spécifiques des mauvais traitements concernant les adolescents sans domicile et fugueurs ainsi que les auteurs de mauvais traitements.

Méthode: Un total de 372 adolescents sans domicile et fugueurs ont été interviewés selon une stratégie d'échantillonnage systématique à Seattle. Ces jeunes ont été interviewés dans les rues et dans des abris par des travailleurs sociaux d'agences pour la jeunesse.

Résultats: A peu près la moitié de ces jeunes ont dit avoir été maltraités et à peu près un tiers avoir subi des abus sexuels. Les filles avaient subi significativement plus d'abus sexuels que les garçons et les jeunes de la minorité sexuelle, significativement plus de sévices physiques et sexuels que les jeunes hétérosexuels. La durée approximative des abus sexuels avait été respectivement de 5 et de 2 ans. Les deux types de sévices étaient évoqués comme extrêmement violents par plus de la moitié de ceux qui les avaient subis. Le nombre approximatif des différents agresseurs physiques et sexuels était de 4 et 3, respectivement. Les parents biologiques étaient en majorité les auteurs d'agressions physiques alors que les auteurs d'agressions sexuelles n'appartenaient la plupart du temps pas à la famille. L'âge approximatif des agresseurs se situait autour de la trentaine et ils étaient des hommes, en majorité, pour les deux types d'abus.

Conclusions: Le mode d'exploitation et de victimisation dans la famille peut avoir des conséquences cumulatives désastreuses sur le développement de ces jeunes quand ils entrent dans l'environnement de la rue. Des programmes d'intervention précoce sont nécessaires pour briser le cycle de l'exploitation et des mauvais traitements dont ces adolescents font l'expérience dans leur famille. Sans intervention, beaucoup de ces jeunes peuvent encourir le risque d'une future exploitation et revictimisation dans la rue.

\section{Resumen}

Objetivo: Examinar una serie de variables específicas del maltrato entre adolescentes "sin techo" y que se han fugado de casa y conocer quienes son los perpetradores del maltrato infantil.

Método: Un total de 372 adolescentes "sin techo" y que se han fugado de casa fueron entrevistados utilizando una estrategia de muestreo sistemático en el área metropolitana de Seattle. Los jóvenes fueron entrevistados en las calles y en los albergues por trabajadores sociales de agencias de atención a la juventud.

Resultados: Aproximadamente la mitad de los jóvenes estudiados notificaron haber sido víctimas de maltrato físico y casi un tercio de ellos habían sido víctimas de abuso sexual. Las mujeres presentaban tasas más elevadas de abuso sexual que los varones y los sujetos homosexuales presentaban tasas más elevadas de maltrato físico y abuso sexual que los heterosexuales. La duración media del maltrato físico y el abuso sexual fue de 5 y 2 años, respectivamente. Ambos tipos de maltrato fueron catalogados como extremadamente violentos por más de la mitad de quienes fueron abusados. El número medio de perpetradores diferentes en los casos de maltrato físico y abuso sexual fue de 4 y 3 respectivamente. La mayoría de los perpetradores del maltrato físico fueron los padres biológicos, mientras que la mayoría de los abusadores sexuales fueron personas ajenas a la familia. Para ambos tipos de maltrato, la edad media de los perpetradores se encontraba entre el final de los 20 años y los primeros 30 años y la mayoría de ellos eran varones.

Conclusiones: La explotación y victimización en la familia puede tener graves consecuencias evolutivas para aquellos jóvenes que entran en el ambiente de los sujetos "sin techo." Se necesitan programas de intervención temprana que rompan el ciclo de explotación y maltrato intrafamiliar. Sin dicha intervención, muchos de estos jóvenes pueden tener riesgo de explotación futura y de revictimización. 